\title{
AIDS, memory and the history of medicine: musings on the Canadian response
}

\author{
Jacalyn Duffin
}

\begin{abstract}
This paper presents the history of AIDS in Canada with special attention to epidemiology, public policy, and social commentary. The interest in medical history sparked by the epidemic is studied in relation to its impact on public health measures. Conversely, the impact of the disease itself on the history of medicine is examined. AIDS seems to have had a greater impact on history in Canada than history has had on the Canadian response to AIDS.
\end{abstract}

(Genitourin Med 1994;70:64-69)

\section{AIDS in Canada}

In Canada, the first AIDS diagnosis was made in February 1982. Notwithstanding the much publicised identification of "Patient Zero," as a Canadian airline attendant who developed Kaposi's sarcoma in $1980,{ }^{1}$ retrospective studies trace cases back to 1979 . As of January 1993, statistics released by the Laboratory Centre for Disease Control in Ottawa revealed that there had been a total of 7,282 cases reported in Canada of which 4,685 were known to have died. Reporting of new cases continued to rise each year until 1990: in 1989 there were 1,192 new cases reported; in 1990, 1,113; in 1991, 1,006; 1992, 407.2 Correction for underreporting and adjustment for delay suggests that the total number of cases may be 10,907 and the decline in numbers of new cases may not have begun until 1992. The large urban centres of Vancouver, Montreal, and Toronto account for two thirds of all cases. The majority of cases have been in homosexual or bisexual men and the disease is now the third most common cause of death in males aged 30 to 39 years. Among the 7,282 total cases were 50 children ( 24 male; 25 female) and 388 women; however, women constitute the fastest growing group of Canadians with AIDS and heterosexual transmission has been identified in more than half. A survey of infection rates among birthing mothers in Quebec revealed the incidence to be $1: 1,638$, twice the presumed national average, and a report released in late July 1992 claimed the incidence of seropositivity among pregnant women in Newfoundland was 1:900, which was ten times higher than the incidence in Manitoba. ${ }^{345}$ HIV-1 testing of donor blood was implemented on 1 November 1985, following a controversial delay that is presently under review by a Parliamentary committee and likely to be challenged in the courts. ${ }^{6-10}$ Intravenous drug users, some of whom had other risk factors, accounted for 407 of all AIDS cases and recipients of blood or blood products accounted for 300 cases. According to the Canadian Hemophilia Society, the estimated HIV seroprevalence among the country's 2000 hemophiliacs is approximately $40 \%$. When doubts were raised about HIV as a causative agent, there appeared an Ontario newspaper report of a patient with AIDS and no apparent HIV infection. ${ }^{11}$

A study of Canadian public health responses cannot automatically be generalised to other countries. Canada has a universal pre-paid health care system that guarantees medical attention, hospitalisation, vaccination, and medication (the latter only in the case of hospitalised patients, welfare recipients, and senior citizens). The economic effects of the AIDS epidemic are no less real but generally less confusing than in the United States. This extends even to life insurance, since it is thought that the relatively smaller Canadian epidemic and the continued freedom to ask about HIV testing will allow insurers to continue providing coverage. ${ }^{12}$ Canada has an enviable human rights record and a Charter of Rights and Freedoms; yet, it also has a social record tending to prudery, intolerance, and slowness to move on reform, especially when it comes to matters pertaining to sex and its products. This can be related to the inherited values of the (until recently) dominant white, Christian population and to the cultural diversity that makes it difficult to find consensus. The "socialised" structure of their health care notwithstanding, Canadians are conservative.

Birth control methods, including condoms and pills, were illegal in Canada until 1969. In the same year, homosexual acts were decriminalised for persons over 21 years. The abortion law was found to be unconstitutional in 1989. At the time of writing (January 1993), the federal government has yet to honour a promise, made in 1986 , to amend the Canadian Human Rights Act to prevent discrimination on the basis of sexual orientation. ${ }^{1314}$ Every Canadian province does have a human rights commission, but only five of ten provinces and the Yukon territory, led by Quebec in 1977, have enacted specific legislation prohibiting discrimination on the basis of sexual orientation. Most provinces waited until the mid-1980s to bring in the changes and interpretation of the laws has been con-
Hannah Chair Histor University, Kingston Ontario, Canada K7L 3N

Accepted for publication 12 February 1993 
troversial: for example, the first case tried under the new law of New Brunswick was heard in July 1992; and later the following month, the Ontario Human Rights commission found the government's practice of denying pension benefits to same-sex partners was discriminatory and the result of an overly narrow interpretation of law. ${ }^{15}$ Legislation to prevent discrimination on the basis of sexual orientation has become a topic of heated debate in Alberta. In 1992, the Canadian Armed Forces abolished the ban on the military service of homosexuals and lesbians after the courts agreed with individuals that their dismissal on this basis had been against the Charter of Rights.

When it comes to AIDS policy, the provinces and the country as a whole, in keeping with Canadian tradition, have been similarly slow to act. In the spring of 1988 the Royal Society of Canada released a report containing 48 recommendations the implementation of which, it claimed, was "imperative, if AIDS is to be controlled in Canada and the possibility of a catastrophic epidemic avoided."16 The recommendations were intended to protect the rights of persons with AIDS as much as they were designed to control the spread of disease and ensure that proper treatments and vaccines could be found. Some of the recommendations were controversial, especially those supporting the generous public funding for widespread frank education about AIDS in all the media (nos. 24 and 25) and those rejecting mandatory testing and nominal reporting for AIDS in any setting (nos. 15-17 and 19-21). Most controversial were the recommendations advocating free needles, syringes, and condoms for IV drug users and inmates of correctional institutions (nos 27-29). Critics pointed out that IV drug use was illegal in Canada and sex was not supposed to occur in prisons.

The government's failure to respond to the Royal Society recommendations resulted in anger and criticism by the contributors. ${ }^{17}$ Norbert J Gilmore, chairman of the National Action Committee on AIDS, resigned on 20 February 1989. His gesture was underpublicised and received no official acknowledgement until more than six weeks later. ${ }^{18}$ Lack of government response also led to the participation of many Canadians in the widely-publicised demonstrations at the Fifth International AIDS Conference in Montreal during June 1989. At the conference, the new federal Minister of Health and Welfare, Perrin Beatty, admitted that there was no Canadian AIDS plan. Beatty blamed his predecessors and announced that he was busy working on legislation to compensate those infected by blood transfusions and to prevent discrimination against HIV seropositive individuals. Despite Beatty's evident sincerity, his remarks had the air of an excuse: after the 1988 election, only the Minister, not the government, had changed. He was sharply criticised and advised to implement the Royal Society recommendations, commissioned by and for the government and completed more than a year before. ${ }^{19} 20$

Since then, a strategic "blueprint,"21 progress statements, ${ }^{22}{ }^{23}$ and flurry of reports, some quite glossy and too numerous to name, have been released tracking the epidemic, extolling the virtues of the government's policy, its sensitivity to and provision for AIDS research and education, and outlining the special needs of women, children, and aboriginals. Zidovudine (AZT), which had been released for restricted use in November 1986 and an open clinical study in May 1987, was made available to asymptomatic HIV carriers in August 1989 and received notice of compliance in October $1990 .{ }^{24}$ DDI $(2,3$ dideoxyinosine) was made available in September 1989.

Legislation prohibiting discrimination against persons suffering with AIDS or related conditions has not yet been enacted and there have been controversial dismissals of teachers and hospital workers. In British Columbia, the medical profession has joined with the Civil Liberties Association to push for such legislation. ${ }^{25}$ However, on 15 August 1989, a British Columbia Cabinet Minister complained that too much money is spent on AIDS, which he referred to as "a self-inflicted wound." He also said, "as a joke," that the New Democratic Party (NDP-then the socialist opposition) should adopt the motto, "Sodomy forever." The Minister's rhetoric may have contributed to his government's defeat by the NDP in the $1991 \mathrm{BC}$ election.

The Canadian Medical Association, supported by the federal department of Health and Welfare, decided to allow physicians to break confidentiality and identify HIVseropositive individuals to their sexual partners. ${ }^{26}{ }^{27}$ However, policy is still murky in the realm of wilful transmission, mandatory testing, and the tracing of contacts.

Alberta is the only Canadian jurisdiction to have introduced legislative changes that specify detention and isolation of a person who "repeatedly and knowingly" puts others at risk of AIDS, despite the fact that the incidence of AIDS in that province is only the fourth highest in the country and less than half the national average. ${ }^{28}$ Other provinces without specific legislation have found citizens guilty of deliberate carelessness or malicious intent to harm through AIDS. In May 1986, a Hull (Quebec) prostitute with AIDS vowed to infect as many people as possible and was not deprived of her liberty until she was physically unable to work; she died in April 1989. An Ottawa man, who had known of his HIV seropositivity since 1986 and yet donated blood in late 1987 , was sentenced to 15 months in jail on 14 August 1989, although his infection had been picked up by screening and there were no serious consequences. A man in Halifax and another in Calgary were convicted on charges of aggravated assault causing bodily harm for knowingly infecting female partners (one pregnant). Late in 1991, a Vancouver doctor was found guilty of criminal negligence and 
ordered to pay $\$ 883,000$ to his patient, who became HIV positive following artificial insemination in $1985 .{ }^{29}$

With respect to containing the AIDS epidemic by coercion, Dr. Gerald Bonham, medical officer of health for Calgary, pointed out that "Laws by their nature work only after the fact. People must protect themselves." ${ }^{30}$ Yet in the face of such statements and against the recommendations of the Royal Society and those of the Canadian Bar Association, ${ }^{31}$ quarantine, isolation, and other similar measures are still debated with fervour. In a peculiar invocation of the past, an author recommended a repressive "sliding scale of personal control measures" that would control some people more than others, claiming it is "necessary in order to avoid the related repressions of the past." 32

Mandatory testing and nominal reporting evoke mixed responses: those in favour argue the benefits to society outweigh the risks to the individual; those against, emphasise the unreliability of the tests and the risk of psychiatric sequelae. ${ }^{33} 3435$ Six provinces have implemented non-nominal reporting, but in the remaining four, identification of seropositive persons is required and in January 1993 a Quebec coroner announced his support for mandatory HIV testing of convicted sex offenders. For would-be immigrants, a complex arrangement prevents mandatory testing, but does not suppress incidental information; knowledge of seropositivity, AIDS, or any other condition associated with excess demands for health care is a criterion for exclusion. ${ }^{36}$

Education programs were finally adopted and given increasing funds, but not without opposition and not without losing a great deal of their impact in an effort to tone down the message in order to avoid offending those who probably needed it least. The installation of a condom machine in a Kingston Ontario high school late in 1991 was met with opposition from some of the teachers and the public; ${ }^{37}$ a needle exchange program in the same city is controversial although 4000 syringes were exchanged in March 1992;38 and the federal prisons (many of which are located in Kingston) are said to be doing an inadequate job with respect to education and sterile needle distribution. A decision to distribute condoms in the federal prisons was made in January 1992, nearly four years after the recommendation was first made. ${ }^{39} 40$

It seems that Canada's AIDS policy (or lack thereof) may be ineffective and has managed to offend scientists, doctors, patients, and the public at large. Reports concerning infection rates in women and sexual behaviour of adolescents suggest that the public information programs are inadequate. ${ }^{414243}$ Scientific researchers, complaining about insufficient funding, have formed their own groups and directories independent of the government initiatives, ${ }^{44}$ while non-scientists have found the medical establishment unwilling to consider alternate clinical trials and fast-tracking. ${ }^{45}$ ACT UP has called Canada's
AIDS strategy a shambles ${ }^{46}$ and doctors complain that they have been left out of the national AIDS programs. ${ }^{47}$ The recent controversy over AIDS aetiology has not received an official response from Canadian authorities now strongly committed to the HIV model. ${ }^{48}$

\section{The impact of history on the Canadian response to AIDS}

Comments on AIDS by historians are becoming routine. ${ }^{49}$ The primarily North American members of the AIDS History Group held their first conference in March 1989 and have begun planning for a second, to be held in the fall of $1993 . .^{50}$ Even non-historical discussions of the disease make reference to the past, if only to call AIDS some sort of "plague" modified by the epithet, "new," "gay," or "latest." Others take pains to present the history of the disease as an introduction to its other aspects, ${ }^{51}$ sometimes its history has been written with the avowed goal of helping to understand the present. ${ }^{52534}$ Historians may avoid predicting, but they do not shrink from warning. Most of these contributions emphasise the importance of preventing the disease without unnecessarily harming people afflicted with it. In other words, historians have adopted a role that tends to support concerns for the rights of individual sufferers.

The same pattern is found in Canada. In preparation for their task, the Royal Society sought information in the form of background papers, one of which was an historical essay by Dr. John M. Last, entitled Natural and Social History of Epidemics ${ }^{55}$ and another an unpublished essay by the present author in answer to the specific question, Are there any lessons from the past to help us understand and manage the AIDS epidemic? The Society also commissioned science-writer, David Spurgeon, to write an explanation of its recommendations for the general public. Spurgeon said: "What we can learn from historical precedents of AIDS is the tremendous potential for irrational cruelty that human contagion brings with it ... Victims of plague, leprosy, and tuberculosis have all suffered social ostracism in various ways and to various degrees. Yet their isolation from the rest of humanity did little or nothing, in itself, to stem the spread of these diseases... For a civilized society, helping the doomed to die with dignity is as important as trying to ensure the safety of those who have, so far, escaped their fate." 5657

Reviewing Spurgeon's "excellent and authoritative guide," historian, Michael Bliss lamented the "macabre price we pay for having thought the laws of hygiene had been repealed." Bliss continued, "At best the study tells us, we can live with AIDS and protect ourselves from it without tramping on its victims rights." And he asked, "If AIDS does finally go the way of smallpox or tuberculosis will we remember... that we are always hostage to our bodies, safe only when we practice some basic rules of hygiene?" 58

But, in Canada, history is used not only in the defence of the rights of victims. The past has also been invoked to demonstrate how 
sloppy, naïve or inhibited we are being now. National arch-reactionary and columnist, Barbara Amiel invoked metahistorical analogy to advocate reversion to 1950 s sexuality and isolation of school children with AIDS. "If bubonic plague or leprosy came back," she maintained, "our first impulse would be to make sure no infected people were allowed in public placeswe would scarcely force employers to hire them." 59 Later, she claimed that unless promiscuity were made socially unacceptable and efforts directed to urging "racial groups" with "looser groupings" to "change their sexual habits... Canadians will cry out for hysterical measures" and "condemn AIDS patients to Devil's Island." 60 A perceptive medical student observed that AIDS has sent "some doctors scurrying in search of Hippocratic loopholes, escape clauses that allow them to treat the sick only as long as [they] don't run the risk of joining their ranks." 61

Elsewhere, in a presentation of the need to punish wilful transmitters of AIDS, an Alberta Report journalist recalled how, "In its fight against syphilis and tuberculosis, the medical community has been granted, and has used, the legal right to quarantine." 62 No attempt was made in this article to explore whether or not the measures had been effective. The same publication recalled "typhoid Mary" in another discussion concerning discipline for those who knowingly transmit AIDS. ${ }^{63}$ Possibly reflecting the conservative orientation of its constituency, commentary in this periodical comprised a significant proportion of the early popular literature on Canadian AIDS.

Have any of the recommendations seemingly endorsed by remembered history had an effect on official response to AIDS? The answer is probably "no." I think that the Royal Society recommendations would have been the same, even if the contributors had not been informed of events in the past. I made this observation in October 1989 at the Yale University Workshop on Memory and the History of Medicine. Several historians present had also been invited to narrate the past in light of AIDS, including Ann Carmichael of University of Indiana Bloomington, an expert on Renaissance plague, and Barbara Rosenkrantz of Harvard, an authority on tuberculosis. We agreed that interest in history by policy-makers seemed to be widespread, but that contributions by historians made little difference to their recommendations, especially when they did not conform to the received view about directions for AIDS management. Professor Rosenkrantz summed it up: "It seemed that my disease was the wrong one, not the right example."

\section{The impact of AIDS on history in Canada}

Since AIDS, there has been an increase in what I call the "Thucydides index:" the number of references to Thucydides' account of the Plague of Athens in the Science Citation Index. The new epidemic invites reexamination of the old. Did polio, influenza, or tuber- culosis incite a similar proliferation of historical activity? During those epidemics was there a parallel discourse, such as we see now, that went beyond humanitarian demands for the sick, to demands for legislation to protect the rights of individuals thought to be at risk? And just as epidemic diseases may shape the medical theories designed to explain them, ${ }^{6465}$ is it not possible they also shape history done during their "constitutional reign:" the subject studied, the questions asked, the evidence examined, and the conclusions reached?

History may have had little effect on Canadian AIDS policy, but AIDS seems to have had an impact on Canadian history. It has not been the only factor in changes observed since 1981. The funding of the Hannah Institute for History of Medicine and the advent of the Canadian Bulletin of Medical History are important new factors in the growth of medical history in Canada; however, they do not account for the relatively large proportion of the new literature in four specific areas, in which the influence of AIDS seems to have been more than coincidental.

First, since 1981, there has been a special interest in the history of infectious diseases with new titles on venereal disease, typhus, influenza, smallpox, and leprosy in the Canadian context. This could be seen as a result of the stimulus provided, in the late 1970 s, by individual historians, such as W.H. McNeill, William Coleman, and Geoffrey Bilson. Nevertheless, three Canadian doctoral theses have appeared since 1981 on the relatively understudied topic of leprosy; two concerned specifically with Canadian leprosy. The first monograph on syphilis in Canada was published in $1987 .{ }^{66}$ From 1918 to 1981 , only five articles had appeared on the 1918 influenza epidemic in Canada, while the first book-length study appeared in $1983 .{ }^{67} \mathrm{~A}$ flurry of activity on smallpox and vaccination has taken place since 1981, including the recent monograph by Michael Bliss on the 1885 outbreak in Montreal. ${ }^{68}$

Second, an informal survey of secondary sources on public health in Canada tends to suggest that the history of public health has been given more attention than in the past. This pattern is also closely related to the socalled "new social history," but the effect of AIDS should not be ignored. ${ }^{69}$ After a burst of activity in the late 1950s (was polio a reminder?), there was a lull until 1978. Almost half $(45 \%)$ of all articles on public health, cited in a 1984 bibliography, had appeared since $1978 ; 30 \%$ since $1981 .^{70}$

Third, for a multitude of reasons not the least of which is the influence of Roy Porter, the patient is ascendant in medical history. ${ }^{71}$ AIDS endorses this orientation and Canadians have become familiar with the personal illnesses of people who have willingly shared their experiences through the media. ${ }^{72} 73$ Just as society listens to AIDS patients, efforts are made to hear the "witness" of past disease. With its predilection for persons often marginalised by society, AIDS causes us to 
remember hard-won freedoms granted only too recently. For example, a graduate student, already convinced of what she would find before she began her research, told me her plan to use diaries and letters in order to explore the "cruelty" of Canadian responses to the 1918 influenza epidemic.

Fourth, many writers have found that measures taken to control past epidemics have been not only inhumane, but also ineffective. Although the events have been "known" (albeit unexplored) for some time, historians are beginning to take a serious look at Grosse Ile, the St. Lawrence River island where immigrants were "quarantined" until all the sick had passed on their cholera or typhus and/or died. ${ }^{74} \mathrm{~A}$ first commemorative assembly was held on the island in the summer of 1989; the site will be declared a national park in 1993.

AIDS is a reminder. It is something that "draws us back from the edge of oblivion ... a point of connection between past and future ... it induce [s] the actual or potential remindee to do or think something that he or she might otherwise forget to do." 75 The ability to truly "remember" anything may be a myth, ${ }^{76}$ but memory can influence both experience and history. History done under the influence of a reminder results in the "telescoping" of events, because it is dominated by a search for precedents. Telescoping of historical narrative may also lead to myth, but that this is not necessarily detrimental for history. Although there is a tendency to perceive myth as false and history as true, the two versions of the story fertilise each other. ${ }^{77}$

With AIDS as a reminder, what is remembered is not only the experience of the disease, ${ }^{78}$ but the existence of history itself. Charles Rosenberg referred to this as "remembering to remember." 79 The Royal Society team did not remember details of past epidemics, but they did remember that they had occurred.

\section{Conclusion}

Canada is in an intensely political mood for repentance, restitution and retribution. ${ }^{80}$ This mood predates AIDS. Citizens (and historians) of a country long proud of its World War II record, welcomed a book that revealed Canadian reluctance to support Jewish immigration just before and during the holocaust. ${ }^{81}$ In 1990, Canadian families of Japanese origin, who had been interned during the second world war, received a formal apology and financial compensation for unjust treatment by Canadian authorities. Government and church officials are beginning to acknowledge the harm wrought in the lives of aboriginal peoples and institutionalised children by the social and educational programs of this century. Serious attention is being given to the actions of police with regard to minorities. The use of history prompted by AIDS may well provide that "conversion of purpose," through which "we can enter into a state of repentance [and] by this means ... find forgiveness." 82
AIDS has reminded us to do history and this remembering has uncovered forgotten episodes and enriched our understanding of our national past. The federal Minister of Health and Welfare even claimed that there would be an impact on the history of the future in his introduction to Canada's first published declaration of its AIDS strategy: " $A$ hundred years from now, when social historians look back at the 1980s they will point to AIDS as one of the major events that shaped the ethos of the time." 83 History has also been used to promote certain proposed actions for AIDS, such as free distribution of needles and condoms, anonymous testing for HIV, and privacy and liberty for persons found to be seropositive; however, the present Canadian policy is a product of a particular political climate and would have been identical even if those making it had not chosen to be informed by historians about other epidemics. There is no monopoly on uses of the past and the same history is sometimes used in support of rejected policies, including mandatory nominal testing of certain people and incarceration for perceived carriers. History remembered in the context of AIDS has not really had an effect on our response so much as it has adorned it and become an instrument of political fashion, a tool to endorse the medico-legal mood of society. What is more, perhaps our desire to make AIDS fit into historical perspective and correspond to certain precedents will mythologise the disease before it is spent.

I thank John Harley Warner and colleagues who attended the Yale Workshop on Memory and the History of Medicine in October 1989. Allan Brandt . Al

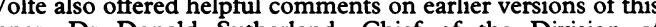
paper. Dr Donald Sutherland, Chief of the Division of
HIV/AIDS Epidemiology at the Canadian Laboratory Centre for Disease Control kindly helped with statistics.

1 Shilts R. And the Band Played on. Politics, People, and the AIDS Epidemic. New York: St Martin's Press, 1987:11. 2 Anonymous. AIDS, Ottawa: Library of Parliament, 1991

Hankins CA, Laberge C, Lapointe N, Lai Tung MT, Racine L, O'Shaughnessey M. HIV Infection among Quebec women giving birth to live infants. Can Med Assoc ₹ 1990;143:885-93.

4 Hankins CA. Women and HIV infection and AIDS in Canada. Should we worry? Can Med Assoc 7 1990; 143:1171-3.

5 HIV rate high in pregnant Newfoundlanders. Globe and Mail 1992 Jul 23:A4

6 Anonymous. Blood test to screen for AIDS virus licensed. Can Med Assoc F 1985;132:950.

7 Canadian Red Cross AIDS Project. Anti-HIV screening in Canadian blood donors. Can Med Assoc $\mathcal{F}$ 1986;35:901.

8 Remis RS, O'Shaughnessey MV, Tsouka C, Growe GH, Schechter MT, Palmer RWH, Lawrence DN. HIV transmission to patients with hemophilia by heattreated, donor-screened factor concentrate. Can Med Assoc F 1990;142:1247-54.

9 Mickleburgh R. Red Cross delay led to AIDS, report says. Globe and Mail 1992 Nov 5:A1, A14.

10 Mickleburgh R. Delay in testing for AIDS cost lives. Globe and Mail 1992 Nov 19:A1, A21.

11 Taylor P. AIDS-like case reported in Ontario, doctors say. Globe and Mail 1992 Jul 24:A5

12 Schiele R. AIDS response: alarm of US insurers toned down here. Financial Post 1987 Mar 16:6.

13 Tarnopolsky W. Discrimination and the law. Don Mills: Richard De Boo, looseleaf supplement, Nov 1991:59.

14 York G. Homosexual rights issue threatening to split York G. Homosexual rights issue threatening to sp
Conservative caucus. Globe and Mail $1992 \mathrm{Apr} 18: \mathrm{A} 6$. Conservative caucus. Globe and Mail 1992 Apr 18:A6.
. Fine S. Gay rights groups to press Ont
status. Globe and Mail 1992 Sep 4:A8.

16 Royal Society of Canada. 1988. AIDS: a perspective for Canadians. Summary report and recommendations. Montreal, Imprimerie Cooérative Harpell, 1988:28.

17 Murray T. "Don't call us, we'll call you," AIDS experts told. The Medical Post 1989 Jan 31:1,43. 
18 Murray T. AIDS Expert Quits. The Medical Post 1989 Apr $11: 1,5$.

19 Murray T. Beatty assails Ottawa on lack of response to AIDS. The Medical Post 1989 Jun 20:2,15.

20 Murray T. Rage over lack of AIDS policy. The Medical Post 1989 May 23:1,5.

21 Canada. HIV and AIDS: Canada's blueprint, Ottawa: Health and Welfare Canada, 1990.

22 Canada. National AIDS Strategy. Building an effective partnership; the federal government's commitment to fighting partnership; the federal government's commitment to

23 Canada. National AIDS Strategy. Progress report. Ottawa: Health and Welfare Canada, 1991

24 Rachlis A. Zidovudine (Retrovir) update. Can Med Assoc $\mathcal{F}$ 1990;143:1177-85.

25 Bryden PL. AIDS and the politics of fear. Policy Options 1989;10:26-8.

26 Sullivan P. Health and Welfare responds to CMA resolutions, supports AIDS stand. Can Med Assoc $\mathcal{f}$ 1988;138:369-70.

27 Chateauvert M, Duffie A, Gilmore N. Human Immunodeficiency Virus Antibody Testing: Counselling Guidelines. Ottawa: Canadian Medical Association, 1990.

28 Cappon P. HIV: the debate over isolation as a measure of personal control. Canadian $f$ Public Health 1991 82:404-8.

29 Taylor P. Should doctors know everything? Globe and Mail, 1991 November 22:A1, A2

30 Heaton G. Dangerous liaisons. Alberta Report 1989 Apr 24:30-2.

31 Tremayne-Lloyd T. Report of the AIDS committee. Toronto: Canadian Bar Association-Ontario, April, 1986.

32 Cappon P. HIV: the debate over isolation as a measure of personal control. Canadian $\mathcal{f}$ Public Health 1991;82: personal 8 .

33 Frank JW, Goel V, Coates RA, Harvey B, Schiralli V. Testing for HIV infection: ethical considerations Testing for HIV infection: ethical con
revisted. Can Med Assoc $\mathcal{F} 1988$;139:287-9.

34 Kleinman I. Examination of HIV antibody testing. Can Med Assoc $\mathcal{F}$ 1988;139:289-91.

35 Hall PF, Somerville MA. The case against HIV antibody testing of refugees and immigrants (letters). Can Med Assoc $\mathcal{F}$ 1990;143:172-3.

36 McGill Center for Medicine, Ethics, and the Law, Responding to HIV? AIDS in Canada, Agincourt: Carswell, looseleaf, immigration, section $2 \cdot 3$ (a) (v)

37 A student defends sex-education programs. WhigStandard, 1992 Apr 21:7.

38 Bannon P. Meeting the silent need for clean needles. Whig-Standard 1992 Apr 15:1,8

39 Appleby T. Jail inmates want AIDS information. Globe and Mail, $1992 \mathrm{Feb} 7$ :A10.

40 Vigil will remember inmates who died of AIDS, neglect. Whig-Standard 1992 Aug10:7.

41 King AJC. Canada youth and AIDS study. Kingston: Queen's University Social Program Evaluation Group, 1988.

42 Bowie WR, Warren WK, Fisher WA, MacDonald NE, Doherty J. Implications of the Canada Youth and AIDS Study for health care providers. Can Med Assoc $\mathcal{F}$ 1990;143:713-6.

43 Manthorne J. Canadian women and AIDS: beyond the statistics. Montreal: Editions communiq'elles, 1990.

44 Sullivan P. Interest heavy as Canada's HIV and AIDS researchers form own organization. Can Med Assoc $\mathcal{F}$ $1991 ; 145: 154$.

45 Schechter M. Open arms and alternative clinical trial designs. Ottawa: Drugs Directorate and the Canadian AIDS Society, 1990

46 Le Bourdais E. AIDS patients concerns at centre stage during Vancouver conference. Can Med Assoc $₹ 1991$ 145:151-2.

47 Berger P. Canada's National AIDS Strategy neglects role of physicians. Can Med Assoc F 1990;143:309-11.

48 Hodgkinson N. AIDS. Can we be positive? The Sunday Times 1992 Apr 26:12-3.

49 Pressman JD. Review Essay. AIDS and the burdens of historians. $\mathcal{F}$ History of Sexuality 1990;1:137-43.

50 Harden VA, Risse G. AIDS and the historian. Proceedings of a conference at the National Institutes of Health, March 20-1, 1989. Washington: US Department of Health and Human Services, 1991.

51 Panem S. The AIDS bureaucracy. Cambridge: Harvard University Press, 1988.

52 Grmek MD. History of AIDS. Emergence and origin of a modern pandemic. Maulitz RC, Duffin J, trans. Princeton: Princeton University Press, 1990:ix.

53 Shilts R. And the band played on. Politics, people and the AIDS epidemic. New York: St Martin's, 1987:xxiii.

54 Fee E, Fox D, eds. AIDS: the burdens of history. Berkeley, Los Angeles, London: University of California Press, 1988:11.

55 Last JM. Natural and social history of epidemics. In AIDS. A Perspective for Canadians: Background Papers for Report on AIDS in Canada. Ottawa: Royal Society of Canada, 1988:9-14.

56 Spurgeon D. Understanding AIDS: A Canadian Strategy. Toronto: Key Porter, 1988:33-4.

57 Spurgeon D. AIDS: No Greater Challenge: Solving the Mysteries. Ottawa: Medical Research Council, 1990

58 Bliss M. Sex and death. Saturday Night 1988; 103,

59 Amiel B. AIDS and the rights of the well. Maclean's 1985 Sep 30:11.

60 Amiel B. The politics of a killer disease. Maclean's 1986 Dec 8:11.

61 Keller AS. AIDS watch. Reflections on Hippocrates in a plague year. Discover 1988 May:26-7.

62 Heaton G. Dangerous Liaisons. Alberta Report 1989 Ap 24:30-2.

63 Simons P. Locking up typhoid Marys: Alberta consider quarantining AIDS carriers. Alberta Report 1988 May $30: 28$.

64 Risse G. Epidemics and medicine: the influence of disease on medical thought and practice. Bull Hist Med on medical tho

65 Stevenson LG. The exemplary disease. $f$ Hist Medicine 1982;37:159-81.

66 Cassel J. The Secret Plague: Veneral Disease in Canada. Toronto: University of Toronto, 1987

67 Pettigrew E. The Silent Enemy: Canada and the Deadly Flu of 1918. Saskatoon: Western Producer Prairie Books, 1983

68 Bliss M. Plague: a Story of Smallpox in Montreal. Toronto: Harper Collins, 1991

69 Mitchinson W, McGinnis JD. Introduction. In Mitchinson W, McGinnis JD, eds. Essays in the History of Canadian Medicine. Toronto: McClelland and Stewart, 1988:7-17.

70 Roland CG. Secondary Sources in the History of Canadian Medicine. Toronto: Hannah Institute for the History of Medicine, 1984

71 Porter $\mathrm{R}$. The patient's view: doing medical history from below. Theory and Society 1985;14:175-98.

72 Whitfield E. Witness: Jim St. James, the Canadian who' survived the longest with AIDS. Saturday Night 1988 Jan 3:36-42.

73 Wilson D. Viewers given chance to share doctor's battle Globe and Mail 1992 August 19:A4.

74 O'Gallagher M. Grosse Ile: Gateway to Canada. Ste Foy, Quebec: Carraig Books, 1984

75 Casey ES. Remembering: a Phenomenological Study. Indianapolis, Bloomington: Indiana University Press, Indianapolis,

76 Rosenfeld I. The invention of Memory: a New View of the Brain. New York: Basic, 1988:6-7.

77 Munz P. History and myth. Philosophical Quarterly 1956; VI: $1-16$

78 Doe J. Remembering AIDS. Harper's Magazine 1989 Apr:24-6.

79 Rosenberg CE. What is an epidemic? AIDS in historica perspective. Daedalus 1989;118:1-17.

80 Strauss S. How to prevent spread of AIDS? Separate politics from statistics. Globe and Mail 1989 Dec 23:D4.

81 Abella I, Trope H. None is Too Many. Toronto: Lester, Orpen and Dennys, 1982.

82 Brockelman P. Of memory and things past. International Philosophical Quarterly 1975;15:309-25.

83 Beatty P. In Canada. HIV and AIDS: Canada's Blueprint. Ottawa: Health and Welfare Canada, 1990. 